\title{
Is it in the Game? Reconsidering play spaces, game definitions, theming and sports videogames
}

\begin{abstract}
From the very first days of digital gaming, sport-themed videogames have been a constant and ever-popular presence. However, compared with many other genres of games, sports-themed videogames have remained relatively underresearch. Using the case of 'sports videogames' this paper advocates a critical and located approach to understanding videogames and gameplay. Unlike many existing theorisations of gameplay, such as the 'magic circle' (Huizinga 1949 [1938]), which theorise play as a break from ordinary life, this paper argues for a consideration of play as a continuation of 'the control of the established order' (Lefebvre (1991 [1974]: 383). It argues that many videogames, and in particular sports videogames, can be understood as 'themed' spaces; which share similarities to other themed locations, such as fast-food restaurants and theme parks. These are 'non-places' (Augé 1995) themed to provide a sense of individuality, control and escape in a society that increasingly offers none.
\end{abstract}

\section{Keywords:}

definitions, games, hyperreality, play, space, sports, Marxism, Lefebvre, themes, theming

\section{Introduction}

Using the case of sports 'themed' videogames, this paper advocates a critical and located approach to understanding videogames and gameplay. Unlike many existing theorisations of gameplay, such as the 'magic circle' (Huizinga 1949 [1938]), or certainly how it has been applied by many contemporary game scholars (such as Salen and Zimmerman 2004), which theorise play as a break from ordinary life, this paper argues for a Lefebvrian-inspired consideration of play as a continuation of 'the control of the established order' (Lefebvre (1991 [1974]: 383). In particular, it argues that many videogames, and in particular sports videogames, can be understood as 'themed' spaces; which share many similarities to other themed locations, such as fast-food restaurants and theme parks.

Though this paper is certainly not the first to utilise the work of the French theorist Henri Lefebvre in an consideration of videogames, and in particular games spaces, it is my argument here that most have simply 'cherry-picked' key 
concepts from Lefebvre, without bringing with them their all-important wider (Marxist) social critique. Hence, this paper attempts to address the call from Fraser (2012: 101) for 'the need and importance of a more thorough reconciliation of videogame studies with Lefebvrian spatial analysis'. In doing so, the paper employs the example and case of sports 'themed' video games. I employ the term 'sports-themed videogames' throughout the paper (unless of course, when referring to, or citing the work of others), the case for doing so will be elaborated as my argument develops.

This argument begins with a consideration of sports as a popular and recurrent genre (or 'theme') of videogame. It then briefly reflects on debates concerning definitions and terminology in the study of videogames. However, the paper argues for the need to move away from fixations with defining and categorising, and rather advocates the need to 'decentre' videogames, and locate them within a wider social context. In light of this, the paper advocates the use of the Lefebvrian-inspired concept of 'theming'. In particular, it argues that many videogames, and in particular sports videogames, can be understood as 'nonplaces' (Augé 1995), which are themed to give (or more specifically 'sell') a sense of individuality, control and escape in a society that increasingly offers none of these.

Though the paper does point to some illustrative examples to evidence its arguments, it is not my intention to offer a focused or textual analysis of specific games; for (as will be elaborated in a moment), to do so, would be to shift too far from Lefebvre's (1991) objective.

\section{Sports as a Theme for Videogames}

Sport constitutes one of the earliest and still best-selling themes for videogames. From the very beginning of videogame history, sport has proved a popular subject for gaming. One of (if not the) very first videogame was William Higinbotham's Tennis for Two; a simple tennis-inspired game developed at Brookhaven National Laboratory in the late 1950s. One of the earliest and most influential home-based videogames was the table-tennis themed game Pong, and sports-themed games continue to be ever popular on most electronic gaming platforms. For example, North American games industry organisation the 
Entertainment Software Association (ESA) suggests that 'sports games' are the third best selling genre of videogames (constituting over $12 \%$ of all videogame sales in 2013), only just behind the rather catch-all category of 'action' games, and the ever popular 'shooting games' (ESA 2014). In the UK, FIFA 2014 was the second best-selling game in 2013, only behind Grand Theft Auto V (Dring 2014), while a similar pattern (but this time featuring a different kind of football) can be seen in the US, where in 2013, Madden NFL 14 was the third biggest selling game behind the latest in the Grand Theft Auto and Call of Duty games (Crossley 2014). However, until fairly recently sports-themed videogames have not received the kind of academic attention afforded many other genres of gaming, and most notably first person shooters (FPS) and massively multiple player online roleplaying games (MMORPG). As David Leonard (2006: 393) argued less than a decade ago 'the field of sports games studies represents a barren wasteland of knowledge'. Of course, things have progressed a little since Leonard made this statement. Videogame studies has seen a rapid expansion over the previous decade or so, and consequently many genres and platforms previously ignored have started to be the focus of research. However, still today, sports-themed video games appear comparatively under-researched when compared with many other genres and aspects of video gaming. As Consalvo, Mitgutsch and Stein, writing in 2013 argued, still relatively 'little ink has been spilled on the topic of sports videogames' (p.2).

Consalvo et al. (2013) identify a small group of academics who were amongst the first to research and discuss (what they term) 'sports videogames'. First, they identify my own work, as being 'one of the first...to study sports videogames' (2013: 3). Some of my earlier work in this area (such as, Crawford 2005a, 2005b) focused on the relationship between sports fan allegiances, participation and playing sports-themed videogames. My work (such as, Crawford 2006, 2008, Crawford \& Gosling 2009) then moved more onto considering the pleasures and uses of sports-themed videogames for their players, and in particular, how gamers often use these a resource to construct (life) narratives both while playing and away from the game screen. 
Consalvo et al. (2013: 3) also highlights the 'pioneering' work of David Leonard (such as, 2004, 2006) on sports videogames and identity, and in particular his consideration of the problematic nature of in-game representations of ethnicity and race. Similarly, Consalvo et al. (2013: 3) draw attention to the work of Darcy Plymire (2009) on how sports videogames remediate the televisual, Lauren Silberman (2009) on athletes who play videogames, and the significant work of Steven Conway (2010) who, amongst other things, provides a detailed analysis of the videogame and players of Pro Evolution Soccer. Of course, Consalvo et al.'s short list is far from exhaustive, and I could certainly suggest that the work of Andrew Baerg (such as 2007, 2008) should be included in any account of early work on this subject; however, what Consalvo et al. do highlight, is that (at least up until that point) there had been very little written on this subject.

In 2013 Mia Consalvo, Konstantin Mitgutsch and Abe Stein's edited collection Sports Videogames became the first book to specifically focus on this genre of videogame, but it has then been subsequently followed in 2014 by another edited collection on the subject, this time edited by Robert Brookey and Tom Oates, entitled Playing to Win: sports, video games and the culture of play. However, even these two books, do not go any significant way in making up for the lost ground on the large number of volumes written about many other videogame genres, and in particular MMORPGs (Bogost 2013). However, this does show a much needed and welcomed interest in an area of videogame research that has previously been fairly fallow.

\section{Defining Videogames}

Perron and Wolf (2009) argue that a set of agreed-upon terms have been slow to develop throughout videogame research. Consider, for example, the variety of terms used by authors to describe our field of study, such as 'games', 'video games', 'videogames', 'computer games', 'digital games', and so forth. Firstly, this is confusing for both authors and readers like. As terms such as 'computer' and 'video' games are sometimes used interchangeably, or at others times to describe different kinds of games. But secondly, there is a much deeper and important debate here. As Perron and Wolf (2009) highlight, this is not a simple and pedantic argument, but rather a debate at the very heart of this emerging field. 
For example, for many authors (such as Mäyrä 2008), the study of videogames is conceptualised as part of a wider study of games, their structure, rules and play, which includes boardgames, sports and similar, in what he (and others) term 'Game Studies'. However, Game Studies needs to be understood as a particular trajectory in this field of research.

For many early writers on videogames these were understood as new forms of media and storytelling — such as, most influentially, Janet H. Murray's 1997 book Hamlet on the Holodeck: the future of narrative in cyberspace. The counter argument to this 'Media Studies'-informed approached (often termed a narratological approach) is to argue that videogames are best understood, not as an evolution in media, but rather as a form of gameplay, and hence studied as such; hence, often termed a 'Games Studies' or 'ludology' approach. Hence, one reason that scholars cannot agree upon suitable terms to describe the objects of their study, is because they do not necessarily agree on the fundamental nature of what it is they are studying; be that, for example, as media or as a game, or both, or possibly something else? Of course, the 'narratology vs. ludology' debate is now fairly well-worn, and to some extent, a debate which has been exaggerated; as often their particular advocates are not as one-sided or entrenched as is sometimes depicted. However, this debate is significant here, as it illustrates the importance of reflecting on how we locate and theorize videogames and gameplay. And, it is out of this interest in defining and theorising games, that Ian Bogost in 2013 - in the Consalvo et al. (2013) collection - posed the question of 'What Are Sports Videogames?'.

\section{Defining Sports Videogames}

Bogost (2013) highlights that 'sports videogames' are often characterised as 'simulations'. A simulation, to use Caillois' (1962) classic categorisation of game types, is a game that is based upon 'mimicry'. That is to say, a game that seeks to, as closely as possible, replicate certain pre-existing mechanisms or conventions. For example, videogames such as Sim City and Microsoft Flight Simulator (as their names' suggest) are examples of simulations. In these, the gamer plays at, respectively, building and managing a city or flying a number of aircrafts, which are (to varying degrees) based upon the mechanism of town planning and 
management and flight controls. Similarly, many sports-themed videogames proclaim their 'realism' as one of their key selling points. For example, the motto of the videogame developer and publisher EA Sports declares 'if it's in the game, it's in the game'. As Leonard (2006: 394) argues 'sports [video]games attempt to blur the lines between the ballpark and the virtual stadium, the athlete and the virtual athlete'. However, drawing on the work of games designer and writer Ernest Adams (2006), Bogost rightly highlights that 'sports videogames' do not aim to simulate all areas of a sport, but rather tend to focus only on one, or a small number, of aspects and mechanisms. As Bogost (2013: 52, citing Adams 2006: 484) writes 'a sports [video]game simulate some aspect of a sport' (emphasis added).

Moreover, it is evident that not all sports-themed videogames attempt to be realistic in their representations and game mechanisms. For example, Leonard (2004) highlights how the EA Sports Street series of games, such as NBA Street and NFL Street, tend to incorporate exaggerated physics and caricatures of athletes. Hence, Bogost argues that the categorisation of sports videogames as a simulation has its limitations; as not all of these seek to accurately mimic sports, and those that do, only mimic certain limited aspects of those sports. Bogost's solution is that we should understand sports videogames as something different and separate from the sports they borrow from or make reference to. Bogost suggests we should therefore understand sports videogames, not as simulations of a sport, but rather as sports in themselves. As he argues, we should allow 'sports videogames to become a kind of sport rather than a type of media about sport' (Bogost 2013: 65). However, in attempting to categorise 'sports videogames' as 'sports', Bogost (as he readily admits himself) opens up a whole new can of worms. As he writes 'sports are weird and hard to pin down' (Bogost 2013: 52). As any sports scholar, or player or association seeking recognition for their pastime as a recognised 'sport' would testify, defining and categorising what a sport is, is extremely problematic. Hence, this is where Bogost's argument falls down, particularly when he takes the rather weak line of argument to suggest that 'just about anything can be taken seriously as...a sport' (Bogost 2013: 53). Declaring that sports videogames can be a sport, because 'anything 
can be', tells us very little about either videogames or the sports they relate to and, as I will argue, this is an important point.

Of course, Bogost is not the first, and by no means the only scholar to consider the relationship between sports and videogames. This is a debate that has been addressed by several authors, including (but not limited to) Brett Hutchins (2008), Nicolas Taylor (2009), TL Taylor (2012), and Emma Witkowski (2012). And, certainly, there is a debate to be had as to whether certain videogames and gameplay can be considered as a sport. This argument dates back to at least the late 1990s when the UK Professional Computer Game Championships unsuccessfully attempted to have competitive gaming recognised by the English Sports Council as a sport. The basis for this argument is that some videogames readily match typical definitions of what a sport is, in that they can involve interpersonal competition, the development and training of skills, the enforcement of rules, attainment of goals, and even levels of coordination and agility (for example, see UK Sports Council 2010). However, most scholars recognise that seeking to define competitive video gaming (often referred to as 'e-sports') as a sport is fraught with difficulties, and it is not the intention of this paper to add to this debate.

However, it is important to note here that competitive video gaming tends in the US and Europe to be linked most notably to the development of first person shooters, such as Doom and Counter-Strike, while in the East, and in particular Korea, competitive gameplay has tended to focus most keenly around strategy wargames such as StarCraft. Hence, significantly, the most popular videogames that are played in a competitive (sports-like) setting, are not sports-themed videogames. Of course, some sports-themed videogames are played in organised competitions and leagues, such as Pro Evolution Soccer (see Conway 2010), but not all, and not even most. Consequently, I find Bogost's suggestion that we need to consider sports videogames as sports, somewhat unhelpful - as most videogames played as e-sports are not sports-themed, and most sports-themed videogames are not played as e-sports.

\section{Decentring Videogames}

Following Dyer-Witherford and de Peuter (2009: xxvi), my argument is that too 
often Games Studies scholars fixate upon the videogame, or their play, at the expense of considering their wider 'political and economic context'. As they continue, there is therefore, a need for a greater recognition of 'social structures, corporate contexts, and institutional forces' (p. xxvii). Here then, I argue for a contextualised or decentred approach to videogame scholarship.

Chris Rojek's (1995) in Decentring Leisure argues that we should not focus on leisure as an isolated object, which needs to be separated out, measured and defined, but rather as an activity subsumed in wider cultural forms and structures. Hence, leisure is not separate from the rest of society, but rather part of wider social relations. Following this line of argument, it is my assertion that sports-themed videogames need to be understood in relation to both their wider social setting, and more specifically, the sports they refer, relate to, and borrow from. And, therefore I would suggest a more profitable theorisation is, following the work of Henri Lefebvre, to consider how play spaces (as with all social spaces), are socially produced.

\section{The Production of Space}

Several writers, such as Aarseth (2007), Neilsen et al. (2008) and Nitsche (2008) (to name but a few) have sought to understand videogames as play spaces. But for Henri Lefebvre in The Production of Space (1991: 383) though certain play and leisure spaces might 'appear on first inspection to have escaped the control of the established order...inasmuch as they are spaces of play...This is a complete illusion...leisure is as alienated and alienating as labour'.

This appears to be in direct contrast to the arguments of Johan Huizinga (1949), or certainly how his reference to the 'magic circle' has been interpreted by many contemporary Game Studies scholars, such as Salen and Zimmerman (2004). The 'magic circle' is one in a list of examples given by Huizinga (1949: 10) along with 'the arena, card-table...the temple, the stage and the screen', which he suggests are 'temporary worlds'. Here rules and norms are established, negotiated and maintained, which do not necessarily apply outside of that particular space and time. However, focusing on play in an isolated space, centres it, and runs the risk of ignoring its wider social context. 
For many Game Studies scholars the magic circle has proved a useful theoretical tool and metaphor for conceptualising how certain rules and norms apply only in certain play spaces, which (to some degree) escape the social constraints of wider society. This is an argument that has been extensively challenged by many, including Taylor (2007), Pargman and Jakobsson (2008), and Crawford (2009), to name but a few; their critique most often focusing on the clear distinction between play and ordinary life, which this theorisation commonly evokes. Consequently, several authors have attempted to move this debate on, by introducing variations on the magic circle, such as Castronova's (2005) 'almost magic circle' or Juul's (2008) 'Puzzle Piece', which seek to blur the play/everyday life boundary. However, the magic circle continues to be a theoretical tool used by many game scholars and designers alike, such as Adams (2010), as a valuable way for understanding the specificities of play spaces.

Lefebvre's argument however, is that the idea that spaces of play can escape the constraints of ordinary life is an illusion. An illusion largely sold by a capitalist industry, which profits from selling this myth of the possibility of an escape from the control and alienation of the everyday. This is a position also explored by fellow French Marxist, Louis Althusser, who suggests that there is no escape from capitalist ideology; there is no 'outside' for either the 'author' or the 'reader', to use Althusser's terms; though this could equally be the 'games designer' and the 'gamer'. However, being in ideology gives the impression that one is, or can be, outside of it. As he argues: 'what thus seems to take place outside ideology...in reality takes place in ideology. That is why those who are in ideology believe themselves by definition outside ideology' (Althusser 1976: 49). The work of Lefebvre has been referenced in some previous considerations of game spaces. For example, and most notably, Espen Aarseth $(2007,2008)$ has employed aspects of Lefebvre's 'spatial triad' of 'representational space', 'representations of space' and 'spatial practices'. Lefebvre's spatial triad is unfortunately never clearly elaborated by the author, but it is evident that it was his attempt to loosely map out fluid processes, which are dynamic and blur together in the production of space. Hence, due to their fluid nature, and their lack of precise definition, there is some discrepancy in how these terms have 
been applied and defined by subsequent authors. For example, Shields (1999) has pointed out how Lefebvre's conception of lived space is often (and easily) confused with perceived space. But we can see 'representations of space' as referring to how spaces are conceptualised and conceived; such as by town planner, architects, engineers, artists, and so forth. 'Representational space' refers to how space is 'lived through associated images and symbols'; it is the 'non-verbal symbols and signs', which 'overlays physical space' (Lefebvre 1991: 39). And 'spatial practices' refers the perceived; that is to say, the practices and routines that create ('secrete', to use Lefebvre's term) the physical space. Hence, in this model the lived everyday experience is the bridging concept between how space is mentally conceived and physically perceived (Elden 2004).

Aarseth (2007: 163) in his application of these concepts suggests that 'computer games are both representations of space (a formal system of relations) and representational spaces (symbolic imagery with a primarily aesthetic purpose)'. Similarly, Guenzel (2007) (drawing on the work of Wolf 1997) refers to videogames as a 'representational space'. However, Lefebvre's triad model was not intended to describe different kinds of spaces. As Merrified (2000: 173) highlights, though Lefebvre only sketches out this triad in a preliminary fashion, it is evident that this is not a typology, but rather a theorisation of aspects of all social spaces. As Fraser (2012: 100) argues 'I believe a more through understanding of Lefebvre's work would suggest that there is a danger in reifying video games as themselves one aspect of his triad model of space'. Many Game Studies scholars, such as Aarseth and others, have often attempted to define games by using categorical forms of organisation (a taxonomy); particularly in relation to defining what constitutes games and games spaces. But the work of Lefebvre needs to be understood not as a taxonomy but rather as a schema. That is to say, not as 'class inclusion' relations, but rather as 'part-whole' relations (Mandler 1984). Hence, Lefebvre's model does not work as a tool for categorising games spaces.

As with the appropriation of Huizinga's magic circle, Lefebvre's representational space appears to have been cherry-picked by some Game Studies scholars, such as Aarseth, without the need to likewise import or even consider its wider 
theoretical context. However, as Merrifield (2000: 170) argues: '[The Production of Space] is a text which is ...quintessentially Marxist...and that I think, shouldn't be forgotten'. As the title of the book suggests, Lefebvre was primarily concerned here with the production of space. Lefebvre here builds upon Marx's concept of commodity fetishism. Just as how Marx suggests the commodity (the fetishised object) hides social relations and process of production, 'we fall into the trap of treating space 'in itself" (Lefebvre 1991: 90). That is to say, by focusing on spaces, we miss the bigger picture; we miss (following Lefebvre' argument) how these are produced by a repressive economy, bourgeois ideology and masculinity.

\section{Applying The Production of Space}

Lefebvre is useful as he adds an important, but previously missing, spatial dimension to Marxist theory. He reveals how capital, labour and technological changes do not just happen in space, but are fundamentally about space (Gottdiener 1985: 197). However, as with many theorists, Lefebvre does not provide us with a set of tools that can be readily or easily applied to the understanding of a particular case or space. As Gottdiener (1985: 196) writes, 'Lefebvre's theory is not very much help as a guide to spatial analysis. It remains more of an emphasis, a focus on space within the context of marxian reasoning'.

In particular, Lefebvre is critical of textual analysis; as he argues, 'the problem is that any search for space in literary texts will find it everywhere and in every guise...What texts can be considered special enough to provide the basis for “textual” analysis?' (Lefebvre 1991: 15). He did believe that 'an already produced space' could be 'decoded...[or] read' (p.17), but only in 'its totality or global aspect' (p.37). That is to say, we cannot single out individual spaces or texts for analysis, but rather analysis needs to focus on the wider context: the societal production of space.

Therefore, a Lefebvrian perspective does not readily lend itself to the (textual) analysis of videogames or game spaces, as Lefebvre's emphasise is a much wider critique of the production of all social space. Therefore, we need to look at how others have sought to develop and apply Lefebvre's work; and I would suggest that Mark Gottdiener's work is particularly helpful here. 
Gottdiener (1985: 197) argues that though Marxist analysis offers us an awareness of 'how space has been altered by such global phenomena as the multinational corporation...it ignores...horizontal linkages...between groups, institutions, and holders of resources'. Hence, Gottdiener proposes a more 'three-dimensional' model, which takes into consideration how capitalist modes of production do not just shape the 'global' and 'corporate cities', but also the 'regional' and the 'suburbs as well' (p.198).

So here, Gottdiener attempts to develop Lefebvre's top-down (macro-level) theory into a three-dimensional (meso-level) analysis. This therefore, takes into account how global capitalist forces manifest themselves at an institutional level, such as the growing importance of consumer spaces; which he considers most notably in his work on theming.

\section{Theming}

It is upon this work of Lefebvre that Gottdiener $(2000,2001)$ develops his conceptualisation of theming. For Gottdiener theming involves the use of 'advertising, branding and other corporate efforts to stimulate consumer demand' (Gotham 2005: 227). Gottdiener argues the origins of theming can be found in the American fast-food diner. As he writes:

...the diner is essentially a simple shed adorned with symbols. The decorated shed became the forerunner for the themed restaurant of today. Now competition amongst fast-food franchises or restaurants, couple with increased affluence and the new consumer norms that support frequent meals outside the home, have pushed eating establishments into the use of thematic devices (Gottdiener 2000: 272).

Themes are about creating a customer 'experience'. For early fast-food restaurants, such as McDonald's, this was about developing a known and consistent brand and dining experience, which could then be easily transported and replicated into any of their numerous outlets across the globe. But as competition increased, and consumers became increasingly demanding, so too have themes become increasingly elaborate, often borrowing from another sources - such as the Hard Rock Café or Planet Hollywood, which draw on the themes of rock music and Hollywood cinema, respectively, to help sell their burgers. Of course, the most strikingly obvious example of contemporary 
theming is the theme park. Here, attractions, rides, shops and exhibitions are unified under one, most often borrowed and applied, theme; such as the Disney brand, which unites the whole into a consistent visitor experience.

Themed spaces, such as, fast-food restaurants, theme parks, and similar, are examples of what Augé (1995) referred to as 'non-places'. Non-places are spaces, which in themselves, lack a history and identity, such as airports, motorway service stations and supermarkets. It is these kinds of sites that are then frequently themed. A theme, identity or brand, is imposed upon a bland canvas to create an exciting and spectacular customer experience. However, 'spectacles must continually stimulate new forms of gratification and revelry if they are to remain attractive and profitable', and as the expectations of the spectacular constantly escalate, 'the extraordinary becomes ordinary' (Gotham 2005: 234).

This is an argument similar to that made by the Neo-Marxist writer Theodor Adorno. Adorno argues that the 'culture industry' (the capitalist industry that produces cultural products aimed at the masses) produces what they know will generate profit. As he writes, '[cultural goods] are produced for the market and aimed at the market' (Adorno 1991: 34). Gottdiener (2001) examines how new spaces such as shopping malls, theme parks, themed restaurants and airports are primarily designed and built to financially benefit those who own or operate them. He argues that simply to provide a threshold to a different experience would indeed be liminal, but creating the element of consumerism renders this a transition from 'generalized participant in everyday life, perhaps as either a pedestrian or auto commuter, to the particular status of consumer' (Gottdiener 2001:10).

Hence, cultural goods become repetitive and standardised objects, simply with a thin veneer of individuality, which give the consumer the sense that what they are buying is somehow different to what they had before. Certainly, it could be argued that a large proportion of the videogame industry is based upon producing sequels or re-makes of existing games, while even new titles tend to draw heavily on the tropes and mechanisms of tried and tested formula (Crawford and Rutter 2006). For example, of the top selling games in the UK in 2012, you need to get to number 20 (Sleeping Dogs) before you find a game that 
is not a sequel or re-make of an existing videogame - and many have questioned the originality of that particular game (for example see, Kain 2012). 2013 was a little better, with the release of The Last of Us, and Minecraft onto consoles, but still the top 100 best selling games in the UK again showed little originality; as evidenced by the slightly tweaked sports-themed sequels FIFA 13, FIFA 14, and Football Manager 2014 in the top 100. As Stallabrass (1996: 105) argues, 'the impetus to move on to the next thing is of course an accurate reflection of consumer fashion...in the yearning for the next [video]game with attendant technical advances... [video]games very quickly become obsolete'.

\section{Sports Theming}

Theming is evident in many aspects of sport. An otherwise bland coffee mug or tshirt is given a brand or theme by emblazoning it with the logo of a sports club, such as the interlocking NY initials of the New York Yankees or the red devil of Manchester United. Similarly, sports club themes have lent themselves to fastfood outlets, such as Manchester United's Red Cafés (Crawford 2004).

Theming, and its associated concept of 'branding', can be seen as part of what Richard Giulianotti (2002) refers to as the 'hypercommodification' of sports. Of course, to some degree commercial interests have always featured in organised sports, but Giulianotti (2002: 29), discussing most specifically the example of English professional association football, argues that from the late-1980s many sports witnessed a rapid influx of capital and control from transnational big business, media corporations, sports equipment manufactures and public relations companies. This hypercommodification has helped transform sports clubs and their celebrity players into 'brands'. The image of the club and its players therefore become the object of consumption, sold to audiences around the world.

Furthermore, some have suggested that the sports venue itself has become increasingly a themed 'non-place'. Though historic sports stadia like Old Trafford, the Nou Camp, or Wrigley Field may have a discernable history and identity, many critics of more contemporary sports venues, such as Neilson (1995: 55), argue that these have become 'plastic objects', disconnected from their surrounding. Neilson (1995) argues that many contemporary sports venues 
have not grown organically within the communities they represent, but rather like shopping malls, are standardised structures lacking unique character and constructed often some distance from cities or residential areas. These structures rise out of nowhere, like a 'cathedral in a beanfield' (1995: 55). They are non-places, but have an identity and history imposed upon them through the application of a sports theme or brand. But this is a brand or theme that can be supplemented or even usurped for the right price, as the name and identity of sports venues, even historic ones, are sold to advertisers. Such as, for example, St. James' Park, the 120-year plus historic home of Newcastle United Football Club (which appears to featured on the front cover of the videogame FIFA 13), which in 2011 was officially renamed the 'Sports Direct Arena' (Dixon 2013).

Discussing the example of association football, Sandvoss (2003) argues that sports have become increasingly 'standardized' and 'rationalized', which allows consumers to select and purchase individualised elements of this fandom. As he writes:

In light of the increasingly standardized and pasteurized semiotic structure of contemporary football, DIY citizenship is progressively transformed into 'IKEA citizenship' in which fans merely choose between interchangeable, ever similar, stereotypical messages and discourses, rooted in a pseudocreative and pseudo-participatory environment. Fans are left to reassemble pre-cut parts with uniform results, from which the only possible digression is complete failure of assembly (Sandvoss 2003: 174).

The contemporary sports stadium, Dixon (2013) suggests, offers a key example of what Bryman (2004) identifies as part of the theming evident in processes of 'Disneyisation'. As with other 'Disneyfied' experiences, the sports stadium increasingly offers differing levels of market segmentation; offering premium level (and premium rate) experiences, such as corporate boxes and hospitality packages, for the more exclusive supporter. This too can be increasingly seen with many videogames, which now frequently offer 'premium' level packages, such as exclusive content, action figures, companions books, or other 'themed' products, which Bryman (2004: 4) would suggest 'increases the inclination to consume'.

\section{Sports-Theming in Video Games}


At their core most videogames have simple and repetitive mechanisms, which are built around a, often pre-existing, game-engine. Like the shopping mall or the contemporary sports arena, they are often prefabricated builds, upon which a skin, theme, or (to use Adorno's language) 'veneer' is applied to give (the appearance of) individuality. As Stallabrass (1996: 87) (mimicking Adorno's critique of the wider culture industry) writes, 'the basic structure of the [video]game is overlaid with a visual veneer'. In many respects, videogames are like the New Town that Lefebvre (1991) considers. They are spaces build upon calculations and bourgeois rationality. They are ordered, enclosed and controlled, which for Lefebvre, signals the end of romance and uncertainty.

This can be most clearly seen with many mobile phone based sports-themed videogames. Many of the most popular sports-themed mobile games, such as $I$ AM PLAYR, Perfect Kick, Flick Kick Football, Real Basketball, and Rugby Kicks (to name but a few), all employ very similar game mechanisms, which primarily involve the gamer flicking the mobile screen to propel a ball towards a goal or net. This similarity in gameplay however, is not just shared amongst sportsthemed games, but is common in many other mobile phone games, such as Paper Toss, where the gamer flicks a ball of paper towards an office wastepaper bin. But what most notably distinguishes games like Perfect Kick from Paper Toss is their sports 'theme' and associated symbols and 'signs'.

Following a Baudrillardian line of argument here, it could be argued that the players of sports-themed videogames are primarily consuming signs or simulacra. They are buying into a representation, brand or theme of a sport, which often bears very little direct relation to its primary referent. Baudrillard's (1983) argument suggests a 'hyperreality' - a society based upon the delivery and consumption of the 'realer than real' - and certainly it could argued that some sports-themed videogames do attempt to offer a 'better than real' experience. For example, the football-themed videogame series FIFA has for some time allowed players to instantaneously slowly replay and dissect their goals from different angles, over and over again; a feature currently unavailable to the footballer, the live spectator and even more advanced than that afforded the television audience. 
In many respects, sports-themed videogames could be seen as a rationalised version of their referent. As Pedercini (2014) argues, videogames are constructed and played out on (various kinds of) computers, which operate through the use of coding. That is to say, videogames have at their core numbers and calculations. As he write: 'videogames are built upon technologies of control and quantification; and are still by and large informed by them...From the eyes of a computer machine, everything is mathematically defined and susceptible to rational calculation' (2014: 62). They turn life into calculations, where choices in-games are goal-orientated and rationalised, and gamers into information economy worker' (Conway \& Finn 2013). This is probably nowhere more clearly seen than in sports-themed video games, such as Football Manager or FIFA, which quantify and attribute numerical values to non-quantifiable attributes, such as passing and shooting skills. What this quantification gives gamers is a sense of control - 'videogames are built upon technologies of control...' (Pedercini 2014: 62, emphasis added).

\section{Controlling the Game}

Kerr et al. (2004) suggest that the pleasures of video gameplay derive from certain key game elements or components, including, intertextuality, narrative, immersion, performance and control. From my earlier work (Crawford 2006) on players of the videogames series Football Manager and Championship Manager, it appears that for many (the illusion of) control is a key part of the appeal of sports-themed videogames. Part of the appeal of sports for many fans has always been a sense of inclusion and participation. Sandvoss (2003), building upon the work of Hills (2002), argues where fans of celebrities ('icons') recognise a clear distinction between themselves and their object of their fandom, sports fandom is more 'textual'. In that, the sports team or club a fan follows is made up of multiple elements and a complex history, which allows the fan to see in the object of their fandom what they value in themselves; it becomes a mirror to themselves, and hence as such, they feel part of the club they follow. This is why sports fans often use the first-person pronoun when referring to the club or team they follow; such as 'we won on Saturday'. And by attending games, singing, chanting, buying the team shirt, or wearing a lucky item of clothing, fans feel they 
have an influence, possibly even some degree of control of the club they (literally) support. It is their club.

However, a succession of writers from the late 1960s onwards, and most notably the work of the Sociologists Ian Taylor (1969) and Chas Critcher (1979) highlight how the increased involvement of big business and the bourgeoisification of sports that were once 'the people's game', such as association football in Britain, has seen the increased disconnection of fans, and a sense of a loss of involvement in, and control, of the clubs that they once felt to be theirs. Whilst recognising that there is a large degree of romanisation of a 'golden era' of football, that possibly never existed, it could be argued, that at least part of the appeal of sports-themed videogames, could be derived from their ability to give the gamer a sense of control, which may be absent elsewhere in their lives.

In videogames, the quantification of life adds to this sense of control. The quantification of sports has a long and well recorded history (see Lenskyj, 1988, for example), which sees numbers and times as key indicators of performance and success, but equally, other aspects of social life are becoming increasingly governed by numbers; such as the 'quantified self', where technology, such as mobile health monitoring apps, allow individuals to monitor their health, exercise and bodily efficiencies (Lupton 2014). As Bauman (1997) argues, in an increasingly uncertain and liquid world, more and more we seek a sense of control, of certainty of authorship, in a world where we increasingly have none. Furthermore, Beck (1992) describes increased self-reflexivity in a 'risk society', where increasing amounts of information are sought to counter the anxieties of the decline of traditional structures and frameworks that once governed social life (Lupton 2014).

Both contemporary videogames and quantified self apps are the product of neoliberalism, which promotes the idea of the active citizen and selfimprovement (Foucault 1977). But here, the quantified self inverts the usual logic; rather than games seeking to simulate existing human movement, the human body becomes the object of greater quantification, control and code; or to use the popular, if somewhat contested, term, 'gamified' (for example, see Deterding 2011). As Stallabrass (1996: 90) writes of videogames, though he 
could equally be discussing the quantified self, 'measured by number, selfimprovement is always unambiguous'.

Also, parallels can be drawn here to Trammell's essay on the paper-based (analogue) game Dungeons \& Dragons. Here Tramell (2014: online) argues that the use of tables, maps and statistics in the game of $D \& D$ (and its kin) are very much the product of their era; which provide the players a sense of order in a world that is 'uncontrollable and scary'.

But behind this the rhetoric of numbers and 'realism', hides ideology (Conway \& Finn 2013). Following Althusser (1976), it is important to see any sense of individual freedom or control as ideology propagated (and often marketed and sold) by capitalism. For Foucault, the body becomes the site of self-discipline, but the internalisation of this discipline manifests itself in our actions and cultural practices. As Stallabrass (1996: 89) argues, 'in computer games, the player not only identifies with the image but controls it in obedience to strict rules of conduct'. But this is an elusive, and imagined, sense of control.

\section{Playing with Unreality?}

Leonard (2006) suggests that certain sports-themed videogames allow the gamer to visit sports venues as a 'tourist'. As he writes '...the attractiveness of these games lies in the ability to play at Pebble Beach or battle at Wimbledon. The tourist or colonization aspect of virtual reality are at the centre of this genre of sports game' (2006: 396). However, as highlighted earlier, many sportsthemed videogames do not necessarily attempt to present a version of reality, but rather consciously play with their unreality. For example, (and as Leonard, 2004, recognises) videogames such as the EA Sports Streets series exaggerate physics and caricature appearance, while the mobile-based game Flick Kick Football Legends has an in-game mechanism that allows the gamer to turn the opposition goalkeeper into a fish or puts bowling skittles in front of the players on the pitch.

As Conway \& Finn (2013) argue, these games hold a mirror up to the sporting world, but it is a carnival mirror, distorting the image and exaggerating certain 
features. Hence, the experience of these videogames may be less a Baudrillardian hyperreality, but more akin to Maxine Feifer's (1985) post-tourist.

For Feifer the post-tourist is not necessarily seeking authenticity, but rather accepts, and at times delights, in the inauthentic. As Julier (2014: 167) writes:

Designing for the post-tourist must therefore involve a strong measure of self-conscious artifice. Situations, events or places may be simulated. At the same time, however, this trickery is deliberately incomplete. There is little point in pretending that the real thing is being delivered.

Hence, the contemporary player of sports-themed videogames may not be, as Leonard (2006) theorises them, a tourist seeking a 'real' (or 'realer than real') experience, but rather a 'post-tourist', who recognises the limitations of the sites they visit. As Stallabrass (1996: 102) writes, 'many [video]games take the form of staged, tourist exploration...[but] as with the exploitation of "heritage" themes...they are collected, combined and packaged as entertainment, inevitably with a strong flavour of pastiche'.

For example, like the visitor to a theme park, the video gamer readily accepts both the waiting and compression of time. For example, Julier (2014) highlights how visitors to Disneyland will regularly queue for hours, just to get on one ride. Rides such as Frontierland, which then compress the entire history of the US presidents into 15 minutes. Sports-themed video games have throughout most of their history often condensed time, turning a 90-minute football match into a few minutes of video gameplay. As Rojek (1985) argues, in an increasingly timepressured society, our leisure tends to be taken in short bursts of energy. However, mobile and social games such as Farmville, and its clones, delay gratification (Pedercini 2014); in that they can involve a substantial period of idle time between actions. This is a technique copied in some mobile sportsthemed videogames, such as Flick Kick Football. Here the gamer is only allowed to play a certain number of matches, before their team must then 'rest' and the gamer wait for an allotted period of time before they can resume play. However, of course, this waiting can be shortened by the gamer making additional in-game purchases. Just like the Fastpass of Disneyland, an additional purchase allows the consumer to bypass much of the waiting time. This, in many ways, signals another 'dedifferentiation' between leisure and retail spaces. Like theme parks 
and shopping malls, game environments becomes spaces for both leisure and the purchase and consumption of goods, such as mobile in-app purchases like the (purchasable) health-boosting injections players can get in Flick Kick Football to overcome the need for a rest period.

Moreover, themed spaces, be that a mall, theme park or videogame, provide their consumers with a sense of individual experience. As Gottdiener (2001: 146) writes, 'successful environments appeal to a variety of cultural orientations. They...give the mass consumers alternative ways of enjoying their themed experience'. Video gamers, like the contemporary sports fans discussed by Sandvoss (2003: 174), therefore become the 'IKEA citizens'; purchasing elements of an experience in bite-size chunks, via in-app purchases or downloadable content, to perpetuate their sense of individualising their game experience or unlocking greater control.

\section{Conclusion}

Sports-themed videogames still remain a comparatively under-research area. In many respects, we are still only scratching the surface in terms of what we can learn about this genre of gaming, what it can tell us about video gaming more generally, and also what it can reveal about the wider nature of our contemporary capitalist society?

A key focus of videogame scholarship, and in particular a 'Game Studies' approach, has been the definition and categorisation of videogames, their nature, structures and their associated gameplay. Though this paper recognises that how we see and conceptualise videogames is crucial in understanding the various perspectives scholars bring to the subject, too often discussions of defining and categorising (video)games leave largely ignored their wider social context. My concern here, is that too often Games Studies focuses on textual analyses, or the play, actions and agency of gamers. But, as illustrated by Herbert Marcuse (1964) in One-Dimensional Man, it is crucial to recognise, that ultimately, capitalism does not care who consumes, or what they do with what they consume, as long as they carry on consuming.

In light of this, this paper seeks to decentre videogames, and rather locate their consideration within a wider, Lefebvrian-inspired, discussion of 'theming'. In 
particular, it argues that sports-themed videogames can be understood as 'nonplaces' (Augé 1995), which are themed to 'sell' (literally and metaphorically) a sense of individuality, control and escape in a society that increasingly offers none of these.

Theming is evident in many areas of society, most obviously in fast food restaurants and theme parks, but can also be seen in the sports industry. Standardised products, such as t-shirts, mugs and scarves, are given a (perceived) added value by the application of a brand or theme. This is significant in a culture industry that has increasingly seen a hypercommodification and disconnection from its working-class roots and origins. Sports brands, themes and even stadiums become purchasable, for the right price. In an industry where fans' influence and control is becoming less apparent, capitalism profits by selling consumers a sense of control, of influence, of support.

Sports-themed videogames therefore represent the most rationalised version of this; which is both a key example and a metaphor of the wider capitalist sports industry. Here, gamers are sold pre-packaged elements of a sport, in a standardized and formulaic format; which in each iteration gets tweaked slightly and given a veneer of individuality. Here the gamer gets to experience a sense of control of a world normally outside of their reach. The videogame turns the unquantifiable into rationalised calculations and code, to give the gamer the sensation of control and direction they lack in relation to the sports they follow, as well as other aspects of the capitalist society in which they live.

The imported nature of theming means that they can be applied to a wide range of different settings and objects. And hence, I would suggest, theming as a useful way for understanding other genres of videogames. For example, Fraser (2012: 101) highlights the various ways Mediterranean cultures have been represented (themed) in videogames. As he: 'in the game Mario Kart Wii (2008) players drive around a themed Mediterranean city' (emphasis added). But this is for other papers or authors to take up.

The title of this paper 'is it in the game?' is of course a reference to, and a play on, the EA Sports' motto 'If its in the Game, it's in the Game'. This, I (Crawford 2008, 
and several others, such as, Baerg 2008 and Conway 2010) have often used as catchy (if somewhat overused) title for previous publications. But what has received less consideration, and is therefore in need of much greater attention, is not what is in the game, but rather what the game is in.

\section{Acknowledgments:}

I would like to thank the organisers and delegates of the 2014 annual Leisure Studies Association conference, where an earlier version of this paper was presented as a conference keynote. I would also like to thank Daniel Muriel (Salford) and Steve Conway (Swinburne) for their comments on earlier drafts of this paper, Jerry Coulton (Leicester) for our discussions of airports, space and place, and Paul Joyce for his thoughts and insights into Althusser.

\section{Reference:}

Aarseth, E. (1997). Cybertext: Perspectives on Ergodic Literature. Baltimore: Johns Hopkins UP.

- (2007). Allegories Of Space: The Question of Spatiality in Computer Games. In F. von Borries, S.P. Walz \& M. Böttger (eds) Space Time Play: Computer Games, Architecture and Urbanism: The Next Level (pp. 44-47). Berlin: BirkHäuser.

- (2008). A Hollow World: World of Warcaft as Spatial Practice. In J. Walker Rettberg, and H. Corneliussen (eds) Digital Culture, Play, and Identity: A World of Warcraft Reader (pp. 111-122). Cambridge: Mass.MIT Press,.

Abercrombie, N. and Longhurst, B. (1998). Audiences. London: Sage.

Adams, E. (2006). The Fundamentals of Game Design. New York: New Riders.

Adams, E. (2010). The Fundamentals of Game Design (2nd Ed.). Englewood Cliffs, NJ: Prentice Hall.

Adorno, T. (1991). The Culture Industry. London: Routledge.

Althusser, L. (1976). Essays on Ideology. London: Verso.

Auge, M (1995). Non-Places: introduction to an anthropology of supermodernity. (Translated by John Howe). Verso: London.

Baerg, A. (2007). Fight Night Round 2, mediating the body and digital boxing. Sociology of Sport Journal, 24 (5), 325-345.

Baerg, A. (2008). "It's (not) in the game": The quest for quantitative realism and the Madden Football fan. In L. W. Hugenberg, P. M. Haridakis \& A. C. Earnheardt (Eds.), Sports mania: Essays on fandom and the media in the 21st century (pp. 218-228). Jefferson, NC: McFarland \& Company.

Baudrillard, J. (1983). In the Shadow of the Silent majorities or, The end of the Social and Other Essays. Paris: Semitext(e).

Bauman, Z. (1997). Postmodernity and its Discontents. Cambridge: Polity Press. Beck, U. (1992) Risk Society: Towards a New Modernity. London: Sage.

Bogost, I. (2013) What are Sports Videogames?'. In Consalvo, M., Mitgutsch, K. \& Stein, A. (eds) Sports Videogames (pp. 50-66). London: Routledge.Bryman, A. (2004). The Disneyization of Society. London: Sage. 
Caillois, R. (1962). Man, Play and Games (trans. M. Barash). London. Thames \& Hudson.

Castronova, E. (2005) Synthetic Worlds: the business and culture of online games, Chicago: University of Chicago Press.

Consalvo, M, Mitgutsch, K \& Stein, A. (2013). Introduction: mapping the field. In Consalvo, M, Mitgutsch, K \& Stein, A. (eds) Sports Videogames (pp. 1-12). London: Routledge.

Conway, S. (2010) "It's In the Game" and above the game: an analysis of the users of sports videogames, Convergence: the international journal of research into new media technologies, 16 (2), 334-354.

Conway, S. \& Finn, M. (2013) Digital Media Sport: Technology and Power in the Network Society. In B. Hutchins \& D. Rowe (eds) Digital Media Sport (pp. 219-234). London: Routledge.

Crawford, G. (2004). Consuming Sport: Sport, Fans and Culture. London: Routledge.

- (2005a). Digital Gaming, Sport and Gender. Leisure Studies, 24 (3), 259-270.

- (2005b) Sensible Soccer: Sport Fandom and the Rise of Digital Gaming. In, J. Magee, A. Bairner, and A. Tomlinson (eds) The Bountiful Game? Football, Identities and Finance (pp. 249-266). London: Meyer and Meyer.

- (2006). The Cult of Champ Man: The Culture and Pleasures of Championship Manager/Football Manager Gamers. Information, Communication and Society, 9 (4), 496-514

- (2008). It's in the Game': sport fans, film and digital gaming. Sport in Society, March/May, 11 (2/3), 130-145.

- (2009). Forget the Magic Circle (or Towards a Sociology of Video Games. Keynote presentation to the Under the Mask 2, University of Bedfordshire, 5 June 2009. Retrieved February 1, 2013 from http://underthemask.wikidot.com/key-note

Crawford, G. and Gosling, V.K. (2009). More Than a Game: Sports-Themed Video Games \& Player Narratives. Sociology of Sport Journal ('Sport \& New Media' Special Issue), March, 26 (1), 50-66.

Crawford, G. and Rutter, J. (2006). Cultural Studies and Digital Games. In J. Bryce and J. Rutter (eds) Understanding Digital Games (pp. 148-165). London: Sage.

Critcher, C. (1979). Football Since the War. In J. Clarke, C. Critcher and R. Johnson (eds) Working Class Culture: Studies in History and Theory (pp.161-184). London: Hutchinson.

Crossley, R. (2014). Best-selling US games of 2013 revealed, Computerandvideogames.com, Retrieved, October 20, 2014 from http://www.computerandvideogames.com/445780/npd-best-selling-usgames-of-2013-revealed/

de Certeau, M. (1984). The Practice of Everyday Life. Berkeley: University of California, Press.

Deterding, S., Sicart, M., Nacke, L., O'Hara, K. \& Dixon, D. (2011). Gamification. using game-design elements in non-gaming contexts. CHI'11 Extended Abstracts on Human Factiors in Computing Systems, 2425-2428.

Dyer-Witherford, N. and de Peuter, G. (2009). Games of Empire. Minneapolis: University of Minnesota Press.

Dixon, K. (2013). Consuming Football in Late Modern Life. Farnham: Ashgate, 
Dring, C. (2013). The 100 best-selling boxed games of 2013, mcvuk.com.

Retrieved, October 20 1, 2014 from

http://www.mcvuk.com/news/read/the-100-best-selling-boxed-games-of2013/0126802

ESA (2014). Essential Facts about the Computer and Video Game Industry 20143, Entertainment Software Association. Retrieved, October 20, 2014 from http://www.theesa.com/facts/pdfs/ESA_EF_2014.pdf

Elden, S. (2004). Understanding Lefebvre: theory and the possible. London: Continuum.

Feifer, M. (1985). Going Places: the way of the tourist from Imperial Rome to present day. London, MacMillan.

Foucault, M. (1977). Discipline and Punish: the birth of the prison. Harmondsworth: Penguin.

Fraser, B. (2012). Why the Spatial Epistemology of the Video Game Matters: metis, vide game space and interdisciplinary theory. Journal of Gaming and Virtual Worlds, 3(2), pp.93-106.

Gotham. K.F. (2005). Theorizing urban spectacles: festivals, tourism and the transformation of urban space. City, 9 (2), July 2005, 225-246.

Gottdiener, M. (eds) (2000). New Forms of Consumption: Consumers, Culture and Commodification. Oxford: Rowman and Littlefield.

Gottdiener, M. (1985) . The Social Production of Space. Austin, University of Texas Press.

Gottdiener, M. (2001). The Theming of America: American Dreams, Media Fantasies and Themed Environments (2 ${ }^{\text {nd }}$ Ed.) Oxford: Westview Press.

Giulianotti, R. (2002). Supporters, Followers, Fans, and Flaneurs: A Taxonomy of Spectator Identities in Football. Journal of Sport and Social Issues, 26 (1), 2546.

Guenzel, S. (2007). Eastern Europe, 2008. In F. von Borries, S.P. Walz \& M. Böttger (eds) Space Time Play: Computer Games, Architecture and Urbanism: The Next Level (pp. 444-449). Berlin: BirkHäuser.

Hills, M. (2002). Fan Cultures. London: Routledge.

Huizinga, J. (1949 [1938]). Homo Ludens: a study of the play-element in culture. London: Routledge.

Hutchins, B. (2008). Signs of Meta-change in Second Modernity: the growth of esport and the World Cyber Games. New Media \& Society, 10 (6), 851-869.

Jenkins, H. (2004). Game Design as Narrative Architecture. In N. Wardrip-Fruin and P. Harrigan (eds) First Person: new media as story, performance and game (pp. 118-130). Cambridge, Mass.: MIT Press.

Julier, G. (2014). The Culture of Design ( $3^{\text {rd }}$ Ed.). London, Sage.

Juul, J. (2008) 'The Magic Circle and the Puzzle Piece'. In S. Günzel, M. Liebe and D. Mersch (eds) Conference Proceedings of the Philosophy of Computer Games 2008, DIGAREC Series 1, Potsdam: Potsdam University press, 56-69. Retrieved, October 20, 2014 from http://opus.kobv.de/ubp/volltexte/2008/2007/pdf/digarec01.pdf

Kain, E. (2012). “Sleeping Dogs” Review - Part One' (Xbox 360), Forbes.com. Retrieved February 1, 2013 fromhttp://www.forbes.com/sites/erikkain/2012/08/14/sleeping-dogsreview-part-one-xbox-360/3/ 
Kerr, A., Brereton, P. Kücklich, J. and Flynn, R. (2004). New Media: New Media Pleasures?. STeM Working Paper: Final Research Report of a Pilot Research Project. Retrieved March 1, 2005 from www.comms.dcu.ie/kerra/source\%20files/text/NMP_working\%20paper \%20final.pdf (no longer available).

Lefebvre, H. (1991 [1974). The Production of Space (trans. D. Nicholson-Smith). Oxford, Blackwell.

Lenskyj. H. (1988) Measured time: Women, sport and leisure. Leisure Studies, 7 (3), 233-240

Leonard, D. (2004). High Tech Blackface - Race, Sports Video Games and Becoming the Other. Intelligent Agent, 4 (2).

- (2006). An Untapped Field: exploring the world of virtual sports. In A.A. Raney and J. Bryant (eds), Handbook of Sports and Media (pp. 393-407). London: Lawrence Erlbaum.

Lupton, D. (2014). Thequantified self movement some sociobgical perspectives. This Sociobgical Life (personal bbg). Retrieved October 21, 2014 from http://simplysociology.wordpress.com/2012/11/04/the-quantitative-selfmovement-some-sociological-perspectives/

Mandler, J.M (1984). Stories Scripts and Scenes: aspects of schema theory. San Diego: University of California Press.

Marcuse, H. (1964). One-Dimensional Man. Boston: Beacon Press.

Marx, K. (1990 [1867]). Capital Vol. 1. London: Penguin Classic.

Mäyrä, F. (2008). An Introduction to Game Studies: games in culture. London: Sage.

Merrifield, A. (2000). Henri Lefebvre: a socialist in space. In M. Crang \& N. Thrift (eds) Thinking Space (pp. 167-182). London: Routledge.

Murray, J. and H. Jenkins (no date). Before the Holodeck: Translating Star Trek. into Digital Media. Retrieved March 1, 2005 from http://web.mit.edu/21fms/wwww/faculty/henry3/holodeck.html (no longer avaibale).

Nielsen, S.E., Smith, J.H. and Tosca, S.P. (2008). Understanding Video Games: the essential introduction. London: Routledge.

Neilson, B. J. (1995). Baseball. In K. B. Raitz (eds) The Theatre of Sport (pp.30-69). Baltimore: John Hopkins University Press,.

Nitsche, M. (2008) Video Game Spaces: image, play, and structure in 3d game worlds, Cambridge, Mass.: MIT Press.

Pargman, D., and Jakobsson, P. (2008). Do You Believe in Magic? Computer Games in Everyday Life. European Journal of Cultural Studies, 11 (2), 225243.

Pedercini, P. (2014). Videogames and the Spirit of Capitalism', in E. Gee and J. Myerson (eds) Time \& Motion...redefining working life (pp.61-67). Liverpool: Liverpool University Press,.

Perron, B. and Wolf, M.J.P. (2009). Introduction. In B.Perron and M.J.P.Wolf (eds) The Video Game Theory Reader 2 (pp1-22). London, Routledge.

Plymire, D. (2009). Remediating Football for the Posthuman Future: embodiment and subjectivity in sports video games. Sociology of Sport Journal, 26 (1), 17-30.

Rojek, C. (1985). Capitalism and Leisure Theory. London, Tavistock.

- $\quad$ (1995). Decentring Leisure: Rethinking Leisure Theory. London, Sage. 
Sandvoss, C. (2003). A Game of Two Halves: football, television and globalization. London: Routledge.

Salen, K. and Zimmerman, E. (2004). Rules of Play: game design fundamentals. Cambridge, Mass.: MIT Press.

Shields, R. (1999). Lefebvre, Love and Struggle. London: Routledge.

Silberman, L. (2009). Double Play: athletes' use of sport video games to enhance athletic performance. (Unpublished) Master's Thesis, Cambridge : MIT.

Stallabrass, J. (1996). Gargantua: manufactured mass culture. London: Verso.

Taylor, I. (1969). Hooligans: Soccer's Resistance Movement. New Society, 7 August, 204-206.

Taylor, N. (2009). Where the Women Are(n't): gender and North American 'progaming' scene. In B. Atkins, H. Kennedy, T. Krywinska (eds), Breaking New Ground: innovation in games, play, practice and theory: proceedings of the 2009 DiGRA conference, London.

Taylor, T.L. (2007). Pushing the Boundaries: Player Participation and Game Culture. In J. Karaganis (ed.) Structures of Participation in Digital Culture (pp. 112-130). New York: SSRC.

- (2012). Raising the Stakes: e-sports and the professionalization of computer gaming. Cambridge, Mass.: MIT Press.

Tramell, A. (2014). From Where do Dungeons Come? Analogue Game Studies, 1(1). Retrieved, August 18, 2014 from http://analoggamestudies.org/2014/08/from-where-do-dungeons-come/

UK Sports Council (2010) Recognition of sports and National Governing Bodies. Retrieved, February 1, 2013 from http://www.sportscotland.org.uk/sporta-z/recognition_of_sports_and_national_governing_bodies/

Witkowski, E. (2012). Inside the Huddle: the sociology and phenomenology of team play in networked computer games'. Unpublished PhD thesis. Copenhagen: IT University of Copenhagen.

Wolf, M.J.P (1997). Inventing Space: towards a taxonomy of on- and off-screen space in video games. Film Quarterly, 51(1), 11-23. 